\title{
Concept of Harmony in the Vision of Our Ancient Seers and its Relevance to Combat the Present Pandemic

\author{
Dr. Paromita Roy*
}

Assistant Professor, Department of Philosophy, Sree Chaitanya College, Habra, West Bengal, India

DOI: $10.36347 /$ sjahss.2020.v08i08.004

| Received: 19.08.2020 | Accepted: 27.08.2020 | Published: 30.08.2020

*Corresponding author: Dr. Paromita Roy

Abstract

Review Article

Material affluence and technological progress have no doubt enabled man to enjoy the comforts of his life but in the process of material gain, man has somewhat transformed himself into a machine. Alienation from nature and greater propensity to rule the whole world has brought more harm to the life of man than gain. The question of nature's crisis in the form of global warming and above all the present pandemic is raising questions about human activity over the planet. Suffering in general known as adhidaivika or that caused by natural disasters on greater investigation reveal human intervention. Can superiority in existence mean human domination and exploitation of natural resources? The present pandemic is raising serious questions about human activity on this planet. Hence, it is high time that we look back to the age old wisdom as latent in our ancient scriptures. With this intention the article tries to unveil the lofty ideals of the Upanișads and also attempts to remember the words of Swami Vivekananda as to how the concept of harmony envisioned by our seers is relevant to settle the present crisis. The idea of Spiritual Unification is the medicine to settle discords and disharmony in the outer world. Our scriptures teach us that we are all parts of the Divine Reality. Only with such Divine Revelation can we build a harmonious and peaceful world.

Keywords: Self-Realization, Harmony, Spiritual Unification.

Copyright @ 2020: This is an open-access article distributed under the terms of the Creative Commons Attribution license which permits unrestricted use, distribution, and reproduction in any medium for non-commercial use (NonCommercial, or CC-BY-NC) provided the original author and source are credited.

\section{INTRODUCTION}

We as humans are all aware of the concept of harmony. Even being in a state of complete dismantle, we can still comprehend what harmony means and how the concept of harmony is essential in restoring individual and social life at large. With progress of society and increasing advancement of technological progress, we humans have transformed ourselves more into robotic engines to keep pace with the outer world. But we often forget that the blind race to material gain will at last fetch us nothing if our inner world is chaotic and unorganized. It is pertinent to state here that a music is felt soothing to our ears because it has the perfect combination and progression of chords. Likewise, if our inner world be organized, outer chaos and disharmony would hardly affect the inner realm of man. But the question is - why talk about harmony of the inner world of man? If harmony of the inner world be so essential then what is the means to restore harmony in the life of man? Search for the answers takes us to a very lofty ideal of our ancient Indian seers. Their vision of harmony introduces us with a totally different identity of man which is devoid of his outer name, fame and material existence. Such an understanding of the true essence of man can help us fight effectively the crisis that we face in the outer world.

My aim in this paper therefore is to focus on the wisdom of our ancient sages as to how the concept of harmony is relevant to combat the present pandemic. It can hardly be denied that the concept of harmony is very effective to settle disputes or avoid undesirable circumstances like suffering.

When we look into our Indian tradition we find that Indian philosophers have widely discussed various sufferings and also the conditions responsible for their emergence. Suffering according to them have been classified under three (03) heads - (i) adhibhautika (due to bodily ailments), (ii) adhidaivika (caused by natural disasters) and (iii) adhyatmika (caused by certain mental conditions viz., loneliness, depression, anxiety etc.). The disasters that we come across such as earthquake, flood, climate change etc are considered as natural disasters and therefore included in the adhidaivika category. It is believed that humans have no role in causing such disasters and therefore they are 
considered as natural or being the acts of God. But suffering in the adhidaivika category brings in the problem of global warming resulting in climate change. A research into the cause of such suffering shows that it cannot anymore be considered as natural disaster and it is more due to human reckless and thoughtless activity. It is true that there are sufferings which afflict individuals or world as a whole and they are at times difficult or perhaps impossible to avoid. But the problems for which we ourselves may be held responsible may to some extent be averted if we investigate 'why' and 'how' such suffering arises. We can of course propose certain measures to overcome the problems in local as well as global level. But then there would arise some other counter measures and thus the very problem remains unsolved as we are trying to find out a solution from the external world. It is to be noted that no measures or even theories would be of any avail unless the check is drawn from within. External norms often fail to be effective as the question that often surrounds those norms is -'Why should one abide by it?' As such, this very question proves the ineffectivity of any external restriction to offer remedy to any particular issue, be it social or even environmental. The excess of carbon emission heating up the earth's atmosphere and thereby affecting the world's climatic condition can hardly be denied to have been caused due to indiscriminate depletion of natural resources. Excess of human greed and the propensity to rule the entire earth has resulted in global warming cannot be considered natural. Hence, disasters which are considered natural, on thorough investigation reveal greater human intervention and hence the term 'adhidaivika' perhaps should not always be interpreted in the way it is generally done. The present pandemic that the entire world is going through cannot also be explained as natural. Delving deeper into the problem of pandemic we realize that it is somewhat the outcome of intense human greed and the desire to rule the earth. Researchers all over the world are engrossed in finding out remedy to the Covid-19 virus as its characteristics and the process of mutation is leaving the scientists in awe. Humans are trapped in their homes and in the period of lockdown the entire nature is trying to take deep breath to do away with the sufferings that humans have inflicted upon it. The period of lockdown is letting us view clear blue sky. Never have we heard chirping of birds so prominently as their voices have been buried underneath the hustle and bustle of our advanced lives. The wild animals are shedding their fear away for the time being and trying to take a walk in their forest homes which they never have been able to do for fear of poachers. Threats of Covid-19 virus are teaching humans a great lesson. Humans have somehow tried to differentiate between wants and needs. Being locked in homes with earnings dropping down, humans have started managing their lives with the basic necessities which is showing them that life does not stop at all in curtailing exorbitant expenses. It is therefore high time that we realize what life actually means. As threats to human life are grave by Covid-19 virus, it is raising questions about human activities on the planet. The non-human animal world has never gone astray or tried to control nature's working. We can of course assert that the non-human animal world can never control nature's working as they are consciousness but not selfconscious of their existence. Humans being selfconscious are therefore the highest creatures on earth. But the question is- Does being the highest creature allow humans greater privilege to use nature's resources without being responsible? Does not superiority in existence demand of humans prudence in action towards the rest of the world? It is undeniable that lack of prudence and sense of irresponsibility in action is posing serious threat to the planet and we are ignorant enough to assess the intensity of such destruction. The present pandemic is raising questions about our morality. It is therefore relevant that we look to back to the wisdom of our ancient seers as to how they have envisioned a world where there is no discord, no asymmetry, no chaos, no anarchy. We feel curious to learn how such a world can be built which so strong from inside. With this intention, the paper is divided into three parts. In the first part we will look into the Upanișadic wisdom, The insight of our Upanișadic seers will help us understand where and how we have gone astray in our lives that is affecting the world as a whole. The second part will focus on the vision Swami Vivekananda towards world peace and harmony. In this section we will try to see how Swami Vivekananda realized the greater relevance of our age old wisdom and tried to bring it back to the lives of common man. A conclusion from all these sections is met at the end.

\section{Role of our ancient scriptures towards world peace}

The perennial philosophy of the Upanișads have much to offer mankind in respect of the outlook they project towards the world. The world for our Upanișadic seers is the revelation of the same Supreme Brahman. The verses like 'Sarvam etat brahma' meaning 'All this is surely Brahman' [1] (Mānḍukya Upanișad 2); 'Idam sarvam yadayana atma' meaning 'All this (manifested universe) is this Atman' [2] (Bṛhadāraṇyaka Upanișad II.4.6); 'Sarvam khalu idam brahman' meaning 'All this is verily Brahman' [3] (Chāndogya Upanișad 3.14.1), show how the Supreme Self is existent in all objects of this world. The Divine Reality for the Upanișadic seers is not only transcendent but also immanent in all objects of this world. The notion of Divine Omnipresence in our Upanișadic literature is a powerful message for spiritual unification of mankind. The phenomenal world being reflection of the same Supreme Reality is considered no less divine. Each and every object of nature upholds the glory of the Supreme Being. Apart from the non-living world, the living kingdom is reflection of the same Divine Reality. If that be the ultimate truth, then how can humans say that there are enemies in the world or someone is a stranger to anyone? As a result of such realization conflicts, discords, violence, hatred which disrupt and 
disturb social peace may be addressed in the light of the Upanișads. It is pertinent to quote here from the Iśa Upanișad which is the smallest of all the principal Upanișads as it contains only 18 verses but it includes in it the essence of all the Upanișads. The first verse of this Upanișad goes as:

om īśavāsyamidami sarvam yatkiñca jagatyām jagat

tena tyakyena bhuñjīthā mā gridhạ̣ kasyaviddhanam (Iśa Upaniṣad 1)

'Om. All this whatsoever moves on the earth should be covered by the Lord. Protect (your Self) through detachment. Do not covet anybody's wealth. (Or- Do not covet for whose is wealth?) 4]'.

The above verse suggests remedy to all our discords and violence. It is undeniable that different sorts of exploitation that we bring on individuals or society at large is with the title of possession we acquire here in this material world. But it is an obvious fact that no one is ever born with wealth and when we die, all our possessions are left behind. The above verse shows that it is the Lord who is the ultimate owner of all worldly things. As such, one should take from this world only that much which is required for his survival and the rest he should not covet. Hence, moderation in sensual enjoyment is the message which this verse puts in front of the human world. Not only will restriction in sensual enjoyment abolish oppression and violence but the problem of global warming as we have stated before can also be addressed. A person moderate in sensual pleasure will always be aware and cautious in his dealing with the natural world. Hence, we can say that an idea for better relation between man and society seems to be suggested in the above verse.

It is very essential that we understand that technological advancement may fetch us a lot of wealth but it can never give us peace as we in the process of money making are moving far away from our perennial teaching that introduces us with the true essence of man. The Upanișads in this respect introduces us with two important terms - Parā vidyā or highest knowledge and Aparā Vidyā or ordinary knowledge. Aparā Vidyā studies external happenings as is done in physical sciences. But Parā vidyā studies the inner dimension of the individual. The Upanișads consider that there is no conflict between Parā vidyā and Aparā Vidyā. It is a process of adding something and not essentially coming into any kind of conflict. So far, our field of investigation has been this objective world or Vișaya but we have not thrown enough light on the Subject or Vișayi who knows dimension of human nature. So long there will remain mankind, Subject or Vișayi as a field of investigation will seem essential as nothing in this world can take the role of a questioner other than human beings. Hence, the Upanișads place greater importance on understanding of this inner aspect of man. Time and again it is asserted in the Upanișads that realization of the Inner Self of man is essential for tackling external problems and discords. A verse from the Svetāśvatara Upanișad goes as:

yadā carmavat ākāśam veșṭayiṣyanti mānavā / tadā daivam avijñāya duḥkhasyānto bhavișyati // (Svetāśvatara Upanișad 6.20)

'Men may (through their technical skill) roll up the sky like a piece of leather; still their will be no end of sorrow for them without realizing the luminous One within [5].'

A question may crop up as to why inner realization of man is essential. To understand it, it is necessary to focus on the outlook that is obtained as a result of spiritual realization. A verse from the Iśā Upanișad says:

yastu sarvāṇi bhūtānyātmanyevanuśyati /

sarvabhūteșu cātmānam tato na vijugupsate // (Iśā Upaniṣad 6)

He who sees all beings in the Self itself, and the Self in all beings, feels no hatred by virtue of that (realization) [6].

This verse highlights the notion of Oneness that is obtained as a result of Self-Realization. The spirit of Oneness can act as a big cementing factor which can restore peace and harmony on earth. When nations are torn apart by hatred, greed, lust etc., the Upanișads try to bridge the gap with the concept of Oneness thereby emphasizing the fact that the underlying Reality is one. We are all One in essence. A man who realizes Oneness with all beings on earth is not moved by sorrow or fear as there is no one to lose and nothing to hate. Such a man is at peace and is not moved by external turmoil. The next verse also uphold similar perspective. Thus goes the following verse:

yasminsarvāṇi bhūtānyātmaivābhūdvijānatah / tatra ko mohạ̣ kạ̣ śoka ekatvamanupaśyatạ̣ // (Iśā Upanișad 7)

When to the man of realization all beings become the very Self, then what delusion and what sorrow can there be for that seer of oneness? (Or-In the Self, of the man of realization in which all beings become the Self, what delusion and what sorrow can remain for that seer of oneness?) [7].

A verse from the Kaṭha Upanișad also speaks in similar tone:

eko vaśī sarvabhūtāntarātmā

ekam் rūpam bahudhā yaḥ karoti /

tamātmastham ye'nupaśyanti dhīrāsteșām

sukham śāśvatam netareșām // (Kaṭha Upaniṣad II.ii.12). 
Eternal peace is for those- and not for the others- who are discriminating and who realize in their hearts Him who -being one, the controller, and the inner Self of all -makes a single form multifarious [8].

The realization of macrocosm in the microcosm is a significant way to deal with outer discords and tensions. It is needed in this period of time that we delve deeper into the roots of our tradition to explore the eternal wisdom of our seers which in fact is a remedy to actions and outlook towards the material world. The relevance of the Upanișadic wisdom is explained beautifully by Swami Vivekananda. His views towards world harmony and peace are made explicit and meaningful with reference to the perennial philosophy of our country. This proves how the wisdom of our Upanișadic seers are relevant to tackle present day problems. With this intention, we move over to the next section of the paper.

\section{Views of Swami Vivekananda towards world peace} In the modern world, Swami Vivekananda has carried down the Spirit of Oneness to the practical field. Swami Vivekananda was apprehensive of mere material progress. In his words:

The view of man as a social individual, and the efforts to make that individual happy and content at that sensory level, is legitimate and productive of good in early stages; but carried too far, it is bound to generate diverse tensions in the individual and society and lead to unfulfilment, due to stagnation of human creative energy at the sensate level and arresting the onwards movement of that energy to the higher spiritual levels of the human personality [9].

Swami Vivekananda was greatly moved by The Greek culture. Time and again he brought the reference of the great Greek philosopher Socrates as to how he placed before man the famous dictum of the Oracle of Delphi-'Man know thyself' which is akin to our Upanișadic doctrine of Self-Realization. Socrates drank the hemlock as he wanted to die for Truth and not to flee like coward. This is the real nature of man that he should sacrifice himself for truth. Swami Vivekananda always emphasized that everything can be sacrificed for Truth but Truth cannot be sacrificed for anything. This is religion according to Swamiji. It is nothing but realization of the Truth. The variety that we look around according to Swamiji is not false. But the question arises how can variety which offers contradiction be true at the same time? In answer to it Swamiji offers a beautiful answer. He says:

Each religion, as it were, takes up one part of the great, universal truth and spends its whole force in embodying and typifying that part of the great truth. It is therefore addition, not exclusion. That is the idea. System after system arises, each one embodying a great ideal; ideals must be added to ideals. And this is how humanity marches on [10].

This is what the Upanișads convey. It is the same Reality which has expressed itself multifariously. How can anyone then deny the multifarious Reality? Each aspect of the Reality is the finite spark of the Infinite. All our great religions emphasize the same thought. It is the realization of Truth and Oneness that will provide foundational stone for love, concern and compassionate feeling towards the entire world. Swamiji believed that there is no God external to our Soul. Only when one realizes God in all beings, one is able to realize God in himself. Swamiji's teachings thus echoe the same thought that the Upanisads in its mahāvākyas reveal which is the innate divinity of man. The four mahāvākyas are:

ayam ātmā brahma

'This Atman (Self of man) is Brahman.' (Mānḍukya Upaniṣad);

aham brahmāsmi

'I am Brahman.'(Bṛhadāraṇyaka Upaniṣad 1.4.10);

tat tvam asi

'That thou art.'(Chāndogya Upanișad 6.8.7);

prajñānam brahma

'Brahman is pure Consciousness.'(Aitareya Upanișad 5.3).

Individuals being spark of the same Divinity, there is no one held high or low. We are all leaves of that Giant tree. As leaves cannot survive without the tree, in the like manner one cannot achieve peace of mind when others are writhing in pain. Therefore, for Swami Vivekananda, to serve the needy, the destitute is the sacred duty of mankind and in it lies the expression of man's moral and ethical behavior. A lot can be bettered in this world if individuals better themselves. Hence, Swami Vivekananda stresses upon the importance of education which emphasizes manmaking and questions whether bookish knowledge can at all make a man educated. To quote his words:

Education is the manifestation of the perfection already in man.... Education is not the amount of information that is put into your brain and runs riot there, undigested, all your life.... We must have life-building, manmaking, character building assimilation of ideas.... The education that does not help the common mass of people to equip themselves for the struggle for life, which does not bring out strength of character, a spirit of philanthropy, and the courage of a lion- is it worth the name?... [11] 
The quote of Swami Vivekananda makes clear that mere bookish knowledge is not education. A person is educated when his entire being is rooted in Truth. Hence, he focuses on wisdom that is the yardstick of measurement of an educated man. In order to be wise, we need to look back to our perennial philosophy which will help combat the crisis that we are facing in the present world. Hatred can never be won by hatred. Only by love can hatred be won. And to win the entire world by love, we need to realize that no one is a stranger to me as we are all parts of the Divine. Only then can we stop harming and destroying our planet. Hence, Swami Vivekananda rightly has shown us the relevance of the eternal teachings of the Upanișads and how they are relevant in terms of present thought and needs.

\section{CONCLUSION}

The paper has tried to deal with at length the crisis of the present world. The pandemic that the entire world is going through is somewhat the outcome of human propensity to rule each and everything of nature. Human tendency to rule and destroy the planet has ultimately brought human life on the verge of destruction. We cannot survive unless nature is protected and respected. We are sustained by nature. We are part and parcel of nature and not ruler of it. In order to understand this truth it is essential that we delve deeper into our scriptures as to how the concept of universal harmony was realized by our sages thousands of years back and how such a concept is relevant to heal and bring together people and nations. We have to realize that whatever contradictions we come by is only at the sensory level but beyond this sensory level, there is only unification. Hence, there is no separation of anything anywhere and it is beautifully expressed in the verse of the Katha Upanișad which goes as:

na iha nānā asti kimcana

There is actually no separation of things in this world (Kațha Upanișad 2.1.11)

Hence, we can say that for the world to be good and pure we have to make our lives good and pure. It is an effect and we are the means. Therefore, let us purify ourselves. Let us make ourselves perfect. Then will come social peace and above all worldly peace. It is time now to remember the great saying from our scripture- 'vasudhaiva kutumbakam'('the entire world is your relation') and it is the message of freedom, peace, bliss and global harmony.

\section{NOTES AND REFERENCES}

1. Swāmī Ranganathananda, The Message of the Bṛhadārañyaka Upanișad, An Exposition of the Bṛhadāranyaka Upanisad in the light of Modern Thought and Modern Needs, Advaita Ashrama, 2005:70.

2. Ibid., The Charm and Power of the Upanișads, Advaita Ashrama, 2005, 10.

3. Swāmī Gambhīrānanda (translated) Eight Upanisads (Volume two), Advaita Ashrama, 2006, 84.

4. Swāmī Gambhīrānanda, Eight Upanișads (Volume One), Advaita Ashrama 2006, 4.

5. Swāmī Ranganāthānanda, quoted in The Message of the Bṛhadāranyaka Upanișad, An Exposition of the Bṛhadāranyaka Upanișad in the Light of Modern Thought and Modern Needs, Advaita Ashrama, 2005, 113.

6. Swāmī Gambhīrānanda (translated) Eight Upanișads (Volume One), Advaita Ashrama 2006, pp-13.

7. Ibid., pp-14.

8. Ibid., pp-208.

9. Swami Ranganathananda, 'Swami Vivekananda and Human Excellence', Harvard University Lecture, Advaita Ashrama, 2013

10. Excerpt from the lecture of Swami Vivekananda on 'The Way to the Realisation of the Universal Religion' delivered at the Universalist Church, Pasadena, California, Jan 28, 1900 Vivekananda World Teacher, His teachings on the Spiritual Unity of Mankind Edited and with an Introduction by Swami Adiswarananda, Rupa and Co pp-39, 2006).

11. Swami Ranganathananda, 'Swami Vivekananda and Human Excellence', Harvard University Lecture, pp-45, Advaita Ashrama, 2013. 